\title{
CONNOTATION FACTOR MODEL OF HEALTH AND WELLNESS TOURISM AND ENTERPRISE DEVELOPMENT PATH: GROUNDED THEORETICAL RESEARCH BASED ON CONSUMER PERSPECTIVE
}

\author{
Kaihua Yang
}

Panyapiwat Institute of Management, Nonthaburi, Thailand

In this paper the connotation factors of health \& wellness tourism in China are systematically explored, based on the grounded theoretical methods and from the perspective of consumers. Then, the connotation factor model is constructed. The model reveals that the connotation of health \& wellness tourism consists of objective environmental factors and subjective perception factors. Objective environmental factors include four main categories: good living conditions, medical and health conditions, ecological climate environment and harmonious humanistic social environment, while the subjective perception factors include two main categories - spiritual pleasure and humanized service. This study provides targeted implementation paths for health \& wellness tourism enterprises in part of formulating scientifically grounded development plans and strategies.

Keywords: health \& wellness tourism; connotation factor model; consumer perspective; development path

\section{Introduction}

Health \& wellness tourism is an innovative model of health industry reform under the new normal in China. It is also an emerging industry within China's national tourism development strategy. With the strong support and promotion on the side of Chinese government, health and wellness tourism has become a bright spot and a new hot spot in the development of China's tourism. Health and wellness tourism industry has also become an important engine promoting China's economic development and indirectly improving people's living standards.

Due to the lack of systematic and in-depth research on the basic theory of health and wellness tourism and scarce guidance concerning the development of this sector, China's health and wellness tourism industry is somewhat empty and blind, and this certainly affects its development as a standalone industry. Deepening the research on the connotation of

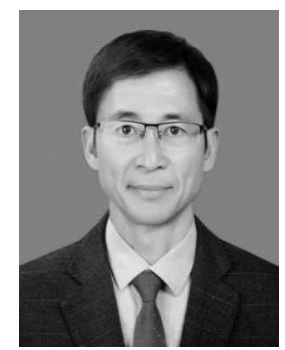

\section{Kaihua Yang}

PhD Student, Chinese Graduate School, Panyapiwat Institute of Management, Nonthaburi, Thailand

Research interests: strategic management; tourism industry, consumers behavior.

E-mail: kai.ya@gmail.com 
health and wellness tourism is conducive to further clarifying its essential characteristics, establishing a clear image of health and wellness tourism destinations, guiding enterprises in formulation of reasonable industrial development plans and strategies, thus improving the performance level of health and wellness tourism enterprises.

\section{Literature review}

Health and wellness tourism is a concept very well familiar for Chinese scholars. In China, the term "Health and Wellness" was first mentioned in the studies on healthcare tourism. In 2004, Liu Liqin mentioned "Health and Wellness" in her article, but did not actually explain the term in detail. Subsequently, Wang Zhao (2009) made a rich interpretation of what is health and wellness tourism, but did not explicitly put forward the connotation.

It is generally considered that health and wellness tourism, namely health tourism and well-being tourism, is a tourism activity based on natural ecological environment, humanistic environment and cultural environment, and also combined with sightseeing, other leisure and recreation activities, working out, so as to achieve the purposes of prolonging life, strengthening body, self-cultivation, medical treatment and rehabilitation.

Ren Xuanyu (2016) specifically described the connotation of health and wellness tourism, arguing that "health and wellness tourism is a logical whole composed of three levels, namely, the physical basis of health and wellness, the need for health and wellness and poetic habitation." On this basis, it can be concluded that health and wellness tourism is a special type of tourism based on good physical conditions, promoting tourists' physical and mental health, enhancing tourists' joyfulness and helping with achieving happiness.

Yin Ping (2019) believed that health and wellness tourism is a new type of tourism, which can be broadly understood as the integration of leisure, recreation and body strengthening on the basis of traditional tourism methods and contents, so that consumers can enjoy physical fitness, medical care, beauty and other services in the context of tourism activities. Health and wellness tourism features such connotations as mini-vacation, experience orientation, slow paced life and also a focus on enjoyment and health.

From the existing research literature we can conclude the following:

(1) There has been little research on the connotation of health and wellness tourism, and the currently available research lacks systematicity and depth;

(2) Descriptive analysis is mostly used in such studies, thus, the research methods are not scientific enough, the research conclusions are at times conflicting, and the understanding of health and wellness tourism is not comprehensive enough.

On the basis of the existing research results and from the perspective of health and wellness tourism consumers, this paper explores the connotation and the components of health and wellness tourism with the help of grounded theoretical methods, in order to provide theoretical and empirical references for enterprises to formulate well targeted health and wellness tourism development plans.

\section{Research methods and data collection}

In our opinion, the grounded theoretical method is the most effective scientific method for exploratory research. As health and wellness tourism is a relatively new research field, 


\section{CONNOTATION FACTOR MODEL OF HEALTH AND}

the research on the connotation thereof is almost absent, as of today. At present, there are no mature variable categories, measurement scales or theoretical assumptions, thus, it is difficult to accurately grasp the connotation components of health and wellness tourism by means of quantitative methods. This research will adopt the ground theory research method to systematically analyze the relevant data through coding and continuous comparative analysis, deeply studying the relevant examples.

Table 1 - Basic information on the respondents

(made by the author)

\begin{tabular}{|c|c|c|c|}
\hline Item & Classification & $\begin{array}{c}\begin{array}{c}\text { Number of people } \\
\text { (persons) }\end{array} \\
\end{array}$ & Proportion \\
\hline \multirow{2}{*}{ Sex } & Man & 9 & $41 \%$ \\
\hline & Woman & 13 & $59 \%$ \\
\hline \multirow{3}{*}{ Age } & $60-69$ years & 6 & $27 \%$ \\
\hline & $70-79$ years old & 7 & $32 \%$ \\
\hline & Over 80 years old & 9 & $41 \%$ \\
\hline \multirow{3}{*}{ Education } & High school or below & 5 & $23 \%$ \\
\hline & Secondary specialized school & 5 & $23 \%$ \\
\hline & College and above & 12 & $54 \%$ \\
\hline \multirow{6}{*}{$\begin{array}{l}\text { Pre-retirement } \\
\text { occupation }\end{array}$} & Administrative staff & 4 & $18 \%$ \\
\hline & Technician & 4 & $18 \%$ \\
\hline & Worker & 1 & $5 \%$ \\
\hline & Teacher & 2 & $9 \%$ \\
\hline & Military officer & 3 & $14 \%$ \\
\hline & Leading cadre & 8 & $36 \%$ \\
\hline \multirow{3}{*}{$\begin{array}{l}\text { The number of } \\
\text { health and } \\
\text { wellness tourism } \\
\text { experiences }\end{array}$} & 1-2 times & 3 & $14 \%$ \\
\hline & 3-4 times & 4 & $18 \%$ \\
\hline & More than 5 times & 15 & $68 \%$ \\
\hline
\end{tabular}

The whole analysis process includes three subprocesses: Open coding, Axial coding and Selective coding. In order to improve the reliability of data sources, this study uses the unstructured interview technology as a method of data collection, selecting health and wellness tourism consumers with relatively great consumption capacity, rich health and wellness tourism experiences and sufficient health and wellness tourism knowledge as interview objects to collect the primary data.

The selected objects are not only from economically developed areas in China, such as first-tier cities (Beijing and Chengdu), but also from economically underdeveloped areas in the north and south of the country, such as Liupanshui in Guizhou and Jiangyou in Sichuan.

$77 \%$ of the respondents were intellectuals, $95 \%$ were professional technicians engaged in management, education and scientific research activities before their retirement. $86 \%$ had been to more than two places for the purposes of health and wellness tourism, and $86 \%$ had more than three health and wellness tourism experiences.

According to the theoretical saturation principle as stipulated by the ground theory, the samples were taken until the newly taken ones no longer provided new important 
information. Finally, 22 interviewees were selected for interviews (see Tab. 1 for more details).

The interviews included face-to-face interviews, telephone and internet interviews, each interview lasting for about an hour. During these interviews, we recorded the interview with the consent of the interviewee, and then sorted out the recorded data immediately after each interview to improve the interview records and memos.

The total of more than 100,000 words of the original data were obtained overall.

\section{Coding of connotative factors for health and wellness tourism}

\section{Open Coding}

Open Coding is a process of conceptualizing the interview data by means of labeling all the encodable sentences or paragraphs obtained in the original interviews after the interview. In the process of coding, we first analyze the original interview data, sentence by sentence, and conceptualize the original data that can be coded. In order to minimize the subjective bias, opinion or other subjective influences of the researcher affecting the reliability of the acquired concepts, we try to use the interviewees' original words, that is, the original oral language of the interviewees themselves as a label to explore the initial concepts, and finally get more than 180 original data inputs and corresponding initial concepts. Because the initial concepts have a relatively low level, a large number, and a certain degree of crossover and overlap, we have eliminated the initial concepts that appear less frequently (less than twice), and only retained the concepts that appear more frequently than three times.

Through analysis, according to the interrelation and logical connection between different concepts, we have reclassified the concepts and summed them up into 11 categories. The original sentences and initial concepts corresponding to each category are shown in Tab. 2. In order to save space, we only select three original sentences and corresponding to the initial concepts for each category.

\section{Axial Coding}

The main task of Axial coding is to find out the main category, that is, to further develop the nature and the level of categories and discover the strict logical relationship between categories after they are extracted by means of open coding. At the same time, all categories are linked together according to the logical relationship, and the internal logical relationship between categories is discovered and established.

Through analysis, it is found that different categories obtained by means of open coding are intrinsically linked at the conceptual level.

According to the relationship and logical order between different categories, the research further sorts out and classify each category, and sums up six main categories. The meaning of each main category and its corresponding open coding category are presented in Tab. 3 . 


\section{CONNOTATION FACTOR MODEL OF HEALTH AND}

Table 2 - Categorization of the connotations related to health and wellness tourism by means of open coding

(made by the author)

\begin{tabular}{|c|c|}
\hline Category & Original statement (initial concept) \\
\hline $\begin{array}{l}\text { Good food and } \\
\text { living conditions }\end{array}$ & $\begin{array}{l}\text { A.1.1 In addition to food, accommodation and transportation } \\
\text { F.1.2 there should be a classification of meals } \\
\text { D.1.3 Accommodation meets the standard of healthcare }\end{array}$ \\
\hline $\begin{array}{l}\text { Convenient traffic } \\
\text { conditions }\end{array}$ & $\begin{array}{l}\text { B.1.5 The traffic inconvenience caused by this place } \\
\text { G.1.4 convenient transportation } \\
\text { H.1.4 There is also convenient transportation }\end{array}$ \\
\hline Complete facility & $\begin{array}{l}\text { H.1.6 good facilities can attract more people } \\
\text { G.1.5 Chengdu has better equipment and residence than Panzhihua } \\
\text { L.3.3 supporting facilities can also be used }\end{array}$ \\
\hline $\begin{array}{l}\text { Have medical } \\
\text { facilities }\end{array}$ & $\begin{array}{l}\text { A.1.2 There are certain medical facilities } \\
\text { F.1.1 The ideal health tourism includes medical facilities } \\
\text { L.1.1 What kind of medical institutions do you have to check our bodies and } \\
\text { measure our blood pressure regularly (medical services are required) }\end{array}$ \\
\hline Healthcare & $\begin{array}{l}\text { C.1.1 I want to live a few more years (conducive to longevity) } \\
\text { D.1.1 Health means healthcare } \\
\text { G.1.1 The first one is health preservation }\end{array}$ \\
\hline $\begin{array}{l}\text { Good climate and } \\
\text { environment }\end{array}$ & $\begin{array}{l}\text { B.1.2 Good climate } \\
\text { C.1.2 find a better environment } \\
\text { D.1.2 The first is the environment }\end{array}$ \\
\hline $\begin{array}{l}\text { Harmonious } \\
\text { humanistic } \\
\text { environment }\end{array}$ & $\begin{array}{l}\text { E.1.3 mutual trust } \\
\text { P.1.4 They are really kind (local people are kind) } \\
\text { Q.1.3 I feel safer as the two old people are more assured together }\end{array}$ \\
\hline $\begin{array}{l}\text { Entertainment, } \\
\text { Enjoyment }\end{array}$ & $\begin{array}{l}\text { K.1.7 There must be entertainment } \\
\text { K.1.10 There should be interested groups, such as singing groups, dance } \\
\text { groups, teams, etc., there should be a literary team } \\
\text { K.1.12 In addition to the natural environment and human environment, such } \\
\text { activities are needed to retain everyone (there must be health and Wellness } \\
\text { activities) }\end{array}$ \\
\hline Invigoration & $\begin{array}{l}\text { E.1.2 relatively happy } \\
\text { G.1.2 The first thing is to go to your favorite place } \\
\text { I.1.17 and have a good time }\end{array}$ \\
\hline $\begin{array}{l}\text { Good service and } \\
\text { good attitude }\end{array}$ & $\begin{array}{l}\text { F.1.4 Personnel have a good service attitude } \\
\text { I.1.23 The boss is generous } \\
\text { P.1.6 It is very caring and patient to the customer's words, and the service } \\
\text { attitude is still quite good }\end{array}$ \\
\hline Everything is good & $\begin{array}{l}\text { E.1.1 a person is very relieved of his friends, boss and all other aspects of the } \\
\text { environment } \\
\text { G.1.7 We old people go out to live in the right place at the right time. } \\
\text { L.5.8 all aspects are better }\end{array}$ \\
\hline
\end{tabular}


Table 3 - Main categories and the axial coding for health and wellness tourism connotations (made by the author)

\begin{tabular}{|c|c|c|c|}
\hline $\begin{array}{l}\text { Classifi- } \\
\text { cation }\end{array}$ & Main category & Categories & Connotation of the category \\
\hline \multirow{7}{*}{ 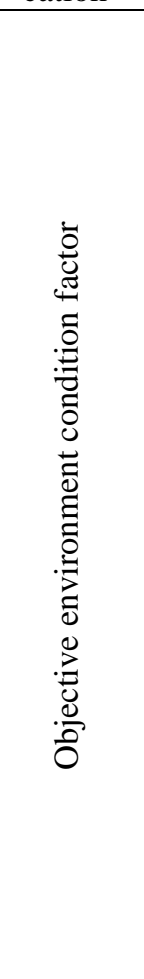 } & \multirow{3}{*}{$\begin{array}{l}\text { Good life } \\
\text { conditions }\end{array}$} & $\begin{array}{l}\text { Good eating and } \\
\text { living conditions }\end{array}$ & $\begin{array}{l}\text { Catering can meet the needs of tourists, with eco- } \\
\text { friendly ingredients, diverse dishes and rich } \\
\text { nutrition. Good accommodation, a feeling of home, } \\
\text { and good rest and sleep quality for tourists. }\end{array}$ \\
\hline & & $\begin{array}{l}\text { Convenient traffic } \\
\text { conditions }\end{array}$ & $\begin{array}{l}\text { Convenient transportation, free choice, not too far } \\
\text { from home, easy to reach. }\end{array}$ \\
\hline & & $\begin{array}{l}\text { Complete facilities } \\
\text { and equipment }\end{array}$ & $\begin{array}{l}\text { All necessary facilities and equipment for living in } \\
\text { the place of residence which can meet the needs in } \\
\text { all the aspects of life. }\end{array}$ \\
\hline & \multirow[b]{2}{*}{$\begin{array}{l}\text { Good medical } \\
\text { and health } \\
\text { conditions }\end{array}$} & $\begin{array}{l}\text { Medical conditions } \\
\text { are convenient }\end{array}$ & $\begin{array}{l}\text { Close to the hospital, or with a small medical center, } \\
\text { patients can see the doctor any time. }\end{array}$ \\
\hline & & healthcare & $\begin{array}{l}\text { The living environment, ecological environment and } \\
\text { climatic conditions are suitable for human } \\
\text { habitation, which is conducive to the health of the } \\
\text { elderly and also for the prevention and reduction of } \\
\text { diseases. }\end{array}$ \\
\hline & $\begin{array}{l}\text { Good climate } \\
\text { and } \\
\text { environment }\end{array}$ & $\begin{array}{l}\text { Ecoclimate. } \\
\text { Excellent } \\
\text { environment }\end{array}$ & $\begin{array}{l}\text { Beautiful natural environment, good air quality, } \\
\text { abundant sunshine in winter, warm climate, cool and } \\
\text { comfortable in summer and moderate air humidity. }\end{array}$ \\
\hline & $\begin{array}{l}\text { Harmonious } \\
\text { humanistic } \\
\text { social } \\
\text { environment }\end{array}$ & $\begin{array}{l}\text { Humanistic society. } \\
\text { Environmental } \\
\text { harmony }\end{array}$ & $\begin{array}{l}\text { The local folk customs are simple, do not exclude } \\
\text { foreign tourists, and the public security situation is } \\
\text { good. The relationship between the boss and tourists } \\
\text { is harmonious, and tourists get along well, care for } \\
\text { each other, help each other and enjoy themselves. }\end{array}$ \\
\hline \multirow{4}{*}{ 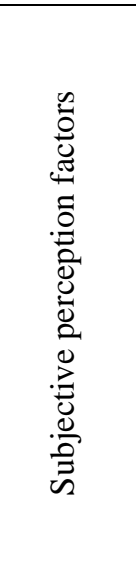 } & \multirow[t]{2}{*}{$\begin{array}{l}\text { Spiritual } \\
\text { pleasure }\end{array}$} & $\begin{array}{l}\text { Entertainment, } \\
\text { enjoyment }\end{array}$ & $\begin{array}{l}\text { Entertainment facilities are complete, entertainment } \\
\text { venues are sufficient, entertainment fees are } \\
\text { reasonable, and entertainment activities are well } \\
\text { organized, so that you can often relax and enjoy } \\
\text { "spiritual food" }\end{array}$ \\
\hline & & invigoration & $\begin{array}{l}\text { Having a good time, relaxing, feeling free and } \\
\text { happy. }\end{array}$ \\
\hline & \multirow{2}{*}{$\begin{array}{l}\text { Humanization } \\
\text { of } \\
\text { Service }\end{array}$} & $\begin{array}{l}\text { Good service and } \\
\text { attitude }\end{array}$ & $\begin{array}{l}\text { The boss has a good service attitude and excellent } \\
\text { service quality, and tourists feel welcome. }\end{array}$ \\
\hline & & Everything is good & $\begin{array}{l}\text { I feel at home, and all conditions are even more } \\
\text { convenient than at home, which can reassure tourists } \\
\text { and their families. }\end{array}$ \\
\hline
\end{tabular}

\section{Selective coding}

Through repeated comparative analysis, the relationship between the categories has gradually emerged. Selective coding is to be carried out further on the relationship between the categories, thus "digging out" the "Core Category" from the main category and describing the overall behavior phenomenon in the form of a story line. In this study, the typical relational structure of the main category is shown in Tab. 4. 


\section{CONNOTATION FACTOR MODEL OF HEALTH AND}

Table 4 - Typical Relationship Structure of the Main Category of Health and Wellness

Tourism Connotation

(made by the author)

\begin{tabular}{|c|c|c|}
\hline $\begin{array}{c}\text { Typical } \\
\text { Relational } \\
\text { Structure }\end{array}$ & $\begin{array}{l}\text { Connotation of the } \\
\text { relationship structure }\end{array}$ & Representative statements of the interviewees \\
\hline $\begin{array}{l}\text { Objective } \\
\text { environmental } \\
\text { conditions } \\
\text { Connotation of } \\
\text { health and } \\
\text { wellness tourism }\end{array}$ & $\begin{array}{c}\text { Good living } \\
\text { conditions, medical } \\
\text { and health conditions } \\
\text { eco-climate in the } \\
\text { environment and } \\
\text { harmonious } \\
\text { humanistic social } \\
\text { environment are the } \\
\text { objective factors for } \\
\text { consumers who } \\
\text { recognize healthy } \\
\text { tourism }\end{array}$ & $\begin{array}{l}\text { A.1.1 My own feeling is that besides food, accommodation } \\
\text { and transportation, there is also a need for doctors and } \\
\text { certain medical conditions which are an important guarantee } \\
\text { for health and wellness tourism. } \\
\text { C.1.2 For the elderly, if they want to live for a few more } \\
\text { years, they should find a place with better environment and } \\
\text { climate. Generally, the elderly are afraid of cold, so they like } \\
\text { to find a warm place. }\end{array}$ \\
\hline $\begin{array}{l}\text { Subjective } \\
\text { perception factor }\end{array}$ & $\begin{array}{l}\text { Spiritual pleasure and } \\
\text { humanized service } \\
\text { are the subjective } \\
\text { factors for consumers } \\
\text { recognizing healthy } \\
\text { tourism }\end{array}$ & $\begin{array}{l}\text { G.1.2 Well-being tourism is mostly for the elderly. For me, } \\
\text { the first thing is to go to my favorite place. } \\
\text { K.1.8 Apart from normal food, accommodation and } \\
\text { environment, there is also a spiritual requirement in terms of } \\
\text { entertainment. } \\
\text { P.1.6 Therefore, I came for them. I think they are kind, and } \\
\text { they are very caring, patient and have a good service } \\
\text { attitude. I like this. }\end{array}$ \\
\hline
\end{tabular}

It has been found above that the factors that make up the connotation of health and wellness tourism include objective environmental conditions and subjective perception factors, which interact and influence each other, and together constitute the connotation of health and wellness tourism in consumers' minds, and "condense" the common image of health and wellness tourism among consumers. Based on this story line, this study constructs a brand new theoretical framework of health and wellness tourism connotation, which we call the health and wellness tourism connotation factor model (see Fig. 1).

\section{Theoretical saturation test}

Theoretical saturation test is an identification standard to decide when to stop sampling, which means that no additional data can be obtained to enable the analyst to further develop the characteristics of a certain category. In order to determine the theoretical saturation, this study has adopted a continuous comparison method.

After continuously comparing the original data from our 22 interviewees, no new categories and relationships have been found. Therefore, it is considered that the "objective environmental conditions - subjective perception factors - health and wellness tourism connotation factor model" is saturated in theory.

The interview data obtained from several representative interviewees has been listed as examples here. 


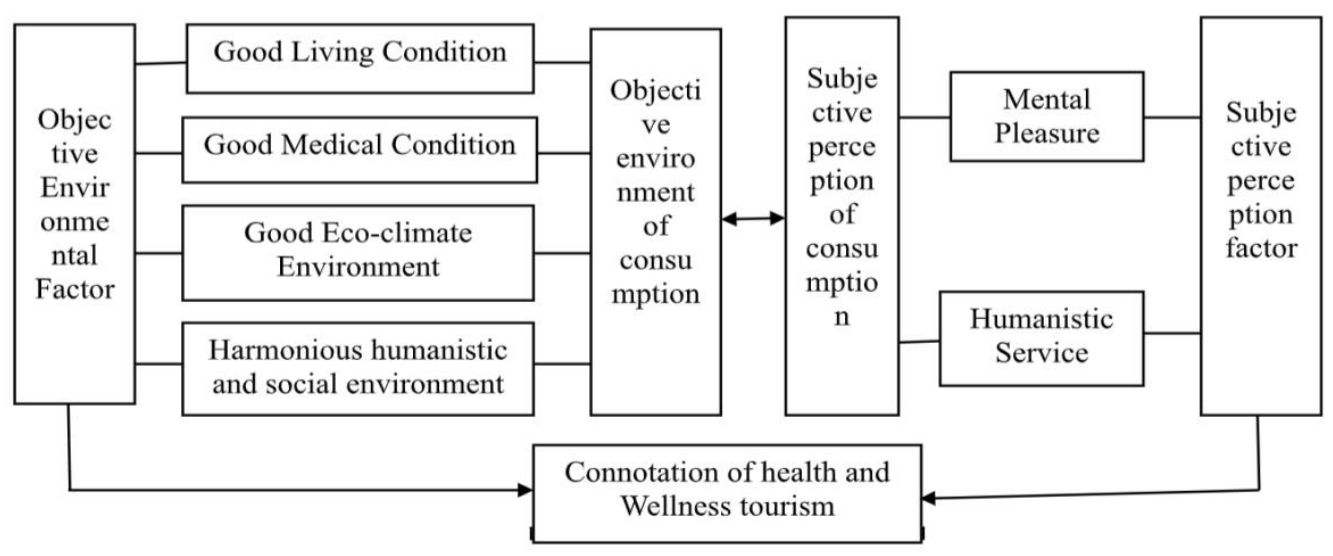

Figure 1 - Connotation structure model of the health and wellness tourism (made by the author)

F.1.1-5: The ideal health and wellness tourism includes medical conditions, having nursing staff, and a variety of living meals, relatively good air, and personnel's good service attitude. At present, this place is not bad for people and respects everyone.

H.1.1 -6: First of all, the environment should be good. Good water quality is also important. After all, the elderly have diseases of varying degrees, so they must have good medical conditions. There should also be convenient transportation. So if all these conditions are achieved, they will be satisfied. Panzhihua is also quite good. Good air and good facilities can attract more people.

O.1.5-7: Panzhihua has another specialty, its temperature, you will basically not get sick here, and your old diseases will not happen. I think it is OK, because it is sunny every day and the air is good. What's more, we are in Qianlong Mountain Villa, whose environment is relatively good, and the surrounding environment is relatively good.

P.1.4, 5: I think people are very kind in this place. Therefore, they don't pay much attention to their personal interests, and I think it is very good.

S.1.1-3: I think that as long as tourism is good for the health of our elderly, it is our purpose. For example, in winter, Chengdu is cold and the smog is serious, so we choose to come to Panzhihua for winter. The air in Panzhihua is good, and also good sunshine.

\section{Model interpretation and research findings}

The above analysis shows that "objective environmental conditions - subjective perception factors - health tourism connotation factor model" can accurately explain the connotation characteristics of health and wellness tourism in consumers' minds. More specifically, the connotation factors of health and wellness tourism can be summarized into 


\section{CONNOTATION FACTOR MODEL OF HEALTH AND}

six main categories: good living conditions, good medical and healthcare conditions, good ecological climate environment, harmonious humanistic and social environment, spiritual pleasure and humanized service, but their status in consumers' minds is different. This is discussed in more detail below.

(1) Good climate and the environment are the prerequisites for the development of health and wellness tourism. Excellent natural environment refers to the beautiful natural environment, good air quality, and abundant sunshine in winter, warm climate, cool summers and moderate air humidity in a health and wellness tourism destination.

All the surveyed consumers have talked about the key position of climate and environment for health and wellness tourism. For example, c.1.1-3 is a retired elderly person, who wants to live for a few more years and find a place with a better environment and a better climate. C.1.4 is afraid of cold and would like to find a warm place. D.1.2 thins that environment is high important for healthcare. It can be seen that good climate plays the key role in the development of health and wellness tourism.

This is consistent with previous research conclusions of other scholars. For example, Ren Xuanyu (2016) believed that "Health and Wellness Tourism is a special holiday tourism based on good physical conditions"; Wang Zhao (2009) thought that recreation tourism is based on natural ecological environment, humanistic environment and cultural environment. Therefore, establishment of health and wellness tourism enterprises must be supported by good climatic and environmental preconditions.

(2) Good living conditions are the basic connotation of health and wellness tourism. Health and wellness tourism is different from "ordinary" tourism since some of the health and wellness tourism destinations assume the need to have a place to live for a relatively long time (at least 3 months in some cases). For such a higher-level lifestyle good living conditions are very important. Good living conditions include three basic categories: good living and eating conditions, convenient transportation and complete facilities. Good eating and living conditions mean that accommodation in a tourist destination can meet not only basic needs of incoming tourists, but also meet their special needs, such as environmental protection of the ingredients used in cooking, variety of dishes, rich nutrition and hygiene of meals; Good accommodation, warmth and comfort, and a feeling of home can ensure tourists may have a good rest and solid sleeping quality.

The interviewees generally emphasized the importance of good living conditions, such as: P.1.8 states that their requirements are not high, but eating must be more environmentally friendly; P.1.7 When you say that customers are treated well, you mean that they should feel like at home. It can be seen that good food and housing conditions are particularly important for the health and wellness tourism consumers, which is an important basic condition for the development of the health and Wellness tourism industry.

This is also in line with Ren Xuanyu's (2016) view that "health tourism is a logical whole composed of three levels, namely, the physical basis of health, the need of health and poetic dwelling". This paper reveals for the first time the importance of good eating conditions for the development of health and wellness tourism. Convenient transportation means that the distance from tourists' home to health and wellness tourism destinations should not be too far, and there should be direct transportation, which should be both convenient and comfortable.

Several interviewees have emphasized the traffic problems many times, such as: g.1.21, flying, we don't like it because the procedure is too troublesome. This shows the importance 
of convenient transportation for health tourism development. Before, to the best of our knowledge, no scholars have studied the traffic problems in health and wellness tourism. Our research has found that convenient transportation has a great influence on health and wellness tourism. Complete facilities and equipment mean that all kinds of facilities and equipment necessary for living in a health and wellness residence are complete, thus meeting the needs of tourists in all aspects of life and also making sure tourists' life in a health and wellness destination is convenient and secure.

These three categories are the basic preconditions for the development of health and wellness tourism and the basic guarantee for human beings pursuing happiness. However, this factor may have different status and functions within the health and wellness tourism. Consumers of health and wellness tourism are usually most concerned about good accommodation conditions, followed by transportation, and only then come living facilities and equipment. Therefore, health and wellness tourism enterprises should focus their attention on good traffic conditions, constantly improve living facilities and equipment, optimizing the accommodation conditions of tourists, upgrading the quality of life of tourists, and meeting the living needs of tourists with different tastes and income levels.

(3) Good medical and healthcare conditions are the guarantee factors for the development of health and wellness tourism. This is in line with Wang Zhao's (2009) viewpoint that "Health and Wellness tourism is well-being tourism". Convenient medical conditions mean, inter alia, that a small medical service spot is set up on the premises of the health and wellness tourism destination, or it is located close to a hospital, so it is convenient to see a doctor or buy other medical services.

Our survey has found that almost all the consumers participating in health and wellness tourism in China are retired elderly people. The physical condition of these people assumes the need to see doctors rather frequently. Therefore, medical services are particularly important for the health and wellness tourism consumers. Almost all the interviewees mentioned medical conditions.

For example, a.1.2 - Another one is to have a doctor and certain medical conditions; H.1.3 After all, the elderly have diseases of varying degrees, so they must have good medical conditions. Therefore, medical conditions are highly important for the development of health and wellness tourism. Thus, enterprises operating in this sector must invest in construction of medical and healthcare facilities, thus forming a good environment for medical treatment and health preservation.

(4) Harmonious humanistic social environment is the incentive factor in the development of health and wellness tourism. Having a harmonious humanistic and social environment means that the folk customs of a health and wellness tourism destination are simple, foreign tourists are not excluded, and the public security situation is good. The relationship between the boss a wellness destination and tourists is also harmonious, and tourists are also caring for each other, helping each other and enjoying themselves overall. Health and wellness tourism is a new way of life.

Foreign tourists who are initially unfamiliar with each other need to live in the same health and wellness tourism destination point for a relatively long period of time. If the local cultural environment is not harmonious, the public security situation is deteriorating, the local people are seriously xenophobic, and the relationship between tourists, locals and bosses is not harmonious, so it is naturally impossible to talk about a happy life in such a place. Therefore, tourists always pay great attention to the local cultural and social 


\section{CONNOTATION FACTOR MODEL OF HEALTH AND}

environment and the relationship with the bosses of the recreation points. For example, F.1.56: At present, this place is not bad for people, respects everyone and respects everyone's opinions; P.1.5: So they don't take their own interests seriously. I think it is very good. This is an important discovery from our study. Harmonious humanistic social environment is very attractive for health and wellness tourists. To attract and stabilize tourists, and improve the occupancy rate and repeated consumption, health and wellness tourism enterprises should strive to cultivate a good humanistic social environment, create a harmonious humanistic ecology, and enhance the sense of security among the tourists coming from abroad.

(5) Humanized service is an important factor affecting health and wellness tourism. Humanized service includes two categories: the bosses' good service attitude and the tourists' feeling good in all the aspects of servicing, thus contributing to the deeper value of experience with health and wellness tourism. The bosses' service attitude and tourists' comprehensive feelings, in their turn, directly affect the post-consumption evaluation of consumers' health and wellness tourism experience, thus further affecting the repeated consumption behavior of health and wellness tourists.

This is consistent with the research conclusions of several scholars earlier working in the same area. For example, p.1.6: I think they are kind and amenable, and they are very caring and patient to customers' words. The service attitude is still quite good. I like this. It can be seen that humanized service has a great influence on tourism consumers. If health and wellness tourism enterprises want to keep tourists for a long time, they must strive to improve the service quality and enhance the tourists' happiness during their stay.

(6) Spiritual pleasure is the deep experience factor related to health and wellness tourism. It includes entertainment and enjoyment, both physical and mental pleasure. Ren Xuanyu (2016) believed that health and wellness tourism is a special type of holiday tourism that promotes tourists' physical and mental health, enhances tourists' joyfulness and helps with achieving happiness through tourism activities.

The Standard of National Health and Wellness Tourism Demonstration Base of China National Tourism Administration define health and wellness tourism as "the sum of all kinds of tourism activities that enable people to achieve a good state of natural harmony in body, mind and spirit". All this indicates to the importance of tourists' physical and mental pleasure when it comes to health and wellness tourism. Our respondents stated directly that health and wellness tourism is b.1.3: wonderful; K.1.8:

Apart from normal food, accommodation and environment, there is also a spiritual requirement, that is entertainment. This accords with Maslow's hierarchy of needs. According to this theory, people must seek spiritual satisfaction once their basic needs in life are met. Before retirement, consumers of health and wellness tourism have good jobs and strong economic consuming capacity.

Therefore, health and wellness tourism must have rich spiritual contents and good spiritual enjoyment. Previous studies have also discussed the spiritual enjoyment of tourists, but their conclusions regarding this component were rather abstract. In this paper, the spiritual enjoyment of tourists is divided into two categories: fun and entertainment, which is of more guiding value for further development of health and wellness tourism destinations.

To develop health and wellness tourism further, we must rely on a good ecological environment, constantly improve living security conditions, strengthen the development of cultural environment, improve service quality, shape a good living and cultural atmosphere, and meet all tourists' life needs, thus providing deep value experience. 


\section{Research conclusion and discussion}

In this study, the connotation of health and wellness tourism is discussed from the consumer's point of view, and the connotation factor model for health and wellness tourism has been constructed. This theory deeply explores the connotation factors of health and wellness tourism, which is beneficial for health and wellness enterprises, as the latter now can more accurately understand the connotation characteristics of health and wellness tourism and thus formulate their future development plans in a more science-based way. This would not only contribute to a better image of health and wellness tourism destinations but also promote more sound development of health and wellness tourism enterprises.

Limitations and shortcomings of this study are mainly as follows: the sample collection has been not comprehensive enough, and the source of all the interviewees is relatively single, most of them came from Sichuan and were retired elderly tourists. This fact, to some extent, may have affected the reliability and validity of our research results. In the future, we plan to select more health and wellness tourism consumers from different regions, different time periods and different age groups. Secondly, our research method is not scientific enough, and the research results need to be further verified.

It is necessary to combine quantitative research methods to conceptualize and operate the categories in this study, and also use quantitative methods such as questionnaire survey or psychological and behavioral experiments to verify and deepen the research conclusions and further improve the reliability and validity of the research results.

\section{References}

Liu, L.Q. (2004). Muwang Mountain National Forest Park. Shaanxi Forestry, 4, 28.

Ren. X.Y. (2016). Health and Wellness Tourism: Connotation Analysis and Development Path. Journal of Tourism Science, 31 (11), 1-4.

Wang, Z. (2009). International Tourism Island: Hainan should write the "prescription" of health and Wellness tourism. Today Hainan, 12, 12.

Yin, P. (2019). Research on Innovative Thinking and Marketing Strategy of Health and Wellness Tourism Products under the Background of Internet. Contemporary Tourism, 08, 21-22.

Paper submitted

Paper accepted for publishing

Paper published online
04 January 2021

26 February 2021

30 November 2021 